Al Qalam: Jurnal Ilmiah Keagamaan dan Kemasyarakatan

https://jurnal.stiq-amuntai.ac.id/index.php/al-qalam

P-ISSN: 1907-4174; E-ISSN: 2621-0681

DOI : 10.35931/aq.v16i2. 935

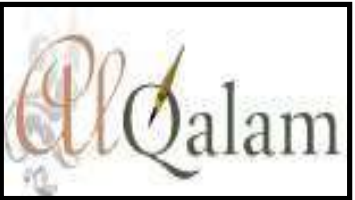

\title{
STRATEGI PEMBINAAN DI PANTI ASUHAN MISBAA HUN MUNIIR KOTA TENGGARONG
}

\author{
Fardy Iskandar \\ fardleo@gmail.com \\ Sekolah Tinggi Agama Islam Samarinda
}

\begin{abstract}
Abstrak
Isu hukum dalam kajian ini adalah sanksi yang diberikan kepada anak Panti asuhan Misbaa Hun Muniir di Kota Tenggarong. Maka permasalahan ini bagaimana strategi pembinaan bagi anak yang melakukan kesalahan di Panti Asuhan Misbaa Hun Muniir Kota Tenggarong dan apakah telah itu sesuai dengan ketentuan peraturan perundangan-undangan. Jenis penelitian dalam kajian ini yaitu penelitian normatif dan penelitian hukum empiris, sebab kajian ini penulis merujuk kepada norma yaitu peraturan perundangundangan khususnya perlindungan anak sebagai dasar untuk mengontrol pelaksanaan di lapangan terkait sanksi yang diterapkan sesuai amanat undang-undang atau tidak. Berdasar permasalahan tersebut dapat disimpulkan, bahwa pemberlakuan pembinaan atas anak di Asuhan Misbaa Hun Muniir Kota Tenggarong yang melakukan kesalahan yaitu dengan pembinaan bertingkat yaitu pelanggan ringan, sedang dan berat. Tingkatan pembinaan tersebut sesuai dengan amanat Undang-Undang Republik Indonesia Nomor 35 Tahun 2014 Tentang Perubahan Atas Undang-Undang Nomor 23 Tahun 2002 Tentang Perlindungan Anak Pasal 59 ayat (2) huruf b Perlindungan Khusus bagi Anak yang berhadapan dengan hukum dilakukan melalui: a. perlakuan secara manusiawi dengan memperhatikan kebutuhan sesuai dengan umurnya.

Kata Kunci: Strategi, Pembinaan, Perlindungan Anak.
\end{abstract}

\begin{abstract}
The legal issue is the sanctions given to the children of the Misbaa Hun Muniir in Tenggarong City. So this problem is what is the punishment strategy for children who make mistakes at the Misbaa Hun Muniir, Tenggarong City, and whether it is following the provisions of the legislation. This research is normative legal research and empirical legal research because, in addition to being based on the law, especially child protection as a basis, the researchers also explore what is in the empirical. So that the sanctions applied are following the mandate of the law or not. Based on these problems, it can be concluded that the application of sanctions against children in the Misbaa Hun Muniir Orphanage in Tenggarong City who made mistakes, namely with graded penalties, namely minor, moderate, and severe violations. The level of punishment is following the mandate of Law of the Republic of Indonesia Number 35 of 2014 concerning Amendments to Law Number 23 of 2002 concerning Child Protection Article 59 paragraph (2) letter b Special protection for children in conflict with the law is carried out through: a. humane treatment by taking into account the needs according to their age.
\end{abstract}

Keyword: Strategy, Punishment, Child Protection

\section{PENDAHULUAN}

Tujuan bermasyarakat sebagai bagian dari cita hukum Indonesia merupakan suatu kesepakatan berupa komitmen dalam mewujudkan perlindungan hak anak. Hal ini bentuk dari perwujudan hak asasi manusia tertuang secara yuridis dalam konstitusi Indonesia, sehingga anak

Al Qalam: Jurnal Ilmiah Keagamaan dan Kemasyarakatan Vol. 16, No. 2

Maret - April 2022 
yang menjalani kehidupan pada masa mendatang mencapai perlindungan, kesejahteraan, kebahagian yang berkualitas. ${ }^{1}$

Anak mempunyai potensi sebagai pejuang bangsa yang memperjuangkan cita bangsa Indonesia. Anak memiliki peran strategis bagi negara sehingga memerlukan pendampingan dan pembinaan dalam rangka memenuhi tumbuh dan kembangnya kedewasaan anak kelak dalam menjalani kehidupan. Sebagai perwujudan upaya pendampingan dan pembinaan terhadap anak hal utama yang penting adalah dukungan dari berbagai pihak termasuk penegak hukumnya. Oleh karena itu, peran penegak hukum untuk memberikan pembinaan pada anak yang melakukan kesalahan, namun catatan penting karena terkait anak maka penegakan hukum dilaksanakan tidak sebagaimana biasanya namun harus secara khusus. ${ }^{2}$

Anak yang berada di lingkungan situasi konflik, lebih cenderung untuk berbuat segala sesuatu yang terlarang. Oleh sebab itu kenakalan anak sangat dipengaruhi oleh lingkungan kehidupannya. Sifat nakal pada anak pengaruhnya tidak hanya mengganggu dan merugikan orang lain, namun pengaruhnya juga berdampak pada dirinya dan masa depannya. Secara umumnya, panti asuhan perlu mengevaluasi hal tersebut, untuk menciptakan kehidupan anak menjadi lebih baik, dengan harapan kelak anak melanjutkan perjuangan bangsa. ${ }^{3}$

Panti asuhan merupakan tempat berlindung anak tanpa orang tua atau orang yang tidak mampu, maka di tempat itu anak mendapat pendampingan sebagai pengganti orang tua. Di sana menerapkan kedisiplinan sebagai rangkaian peraturan-peraturan mengenai tingkah laku anak, sebab seorang anak merupakan aset negara yang kelak melanjutkan kepemimpinan untuk masa depan yang baik. Setiap anak memiliki kepribadian berbeda serta berbagai pula permasalahan, sehingga pengasuhannya dalam pengaturan untuk menciptakan keseimbangan di lingkungan panti asuhan. Namun jika seorang anak atau sekumpulan anak melanggar peraturan tata tertib, sehingga terciptanya ketidakseimbangan, sebab pelanggaran tersebut tidak hanya mendatangkan kerugian diri sendiri tetapi juga berbagai pihak.

Mengembalikan keseimbangan dalam panti asuhan dengan menegakan sanksi, hal tersebut bertujuan untuk menghentikan perbuatan yang tidak dikehendaki, sehingga tumbuh kesadaran diri. ${ }^{4}$ Keberadaan pembinaan yang tepat jika berdampak baik atau bernilai pedagogis. Nilai pedagogis memposisikan pembinaan bagian dari keperluan, sehingga ditujukan untuk dapat

1 Tedy Sudrajat, Perlindungan Hukum Terhadap Hak Anak Sebagai Hak Asasi Manusia Dalam Perspektif Sistem Hukum Keluarga Di Indonesia, Kanun Jurnal Ilmu Hukum, Vo. 13, No. 2, 2011, hlm. 112-113

2 Mohammad Taufik, Wenny Bukamo dan Syaiful Azri, Hukum Perlindungan Anak, Dan Penghapusan Kekerasan Dalam Rumah Tangga, (Jakarta: PT Rineka Cipta, 2013), cet. ke I, hal. 1.

${ }^{3}$ Maidin Gultom, Perlindungan Hukum Terhadap Anak dalam Sistem Peradilan Pidana Anak di Indonesia, (Bandung: PT Refika Aditama, 2014), cet. ke IV, hal. 2.

${ }^{4}$ Iwan Prayitno, Anakku Penyejuk Hatiku, (Bekasi: Pustaka Tarbatuna, 2004), cet. ke II, hal. 416.

Al Qalam: Jurnal Ilmiah Keagamaan dan Kemasyarakatan Vol. 16, No. 2

Maret - April 2022 
menyumbangkan atas perkembangan perilaku akhlak anak. Perkembangan perilaku akhlak yang dimaksud tersebut adalah kesadaran dan kerelaan sesuai nilai harkat dan martabat. Selain itu keberadaan pembinaan sebagai kontrol perilaku anak sehingga selalu melakukan kebaikan dan terhindar dari perbuatan terlarang. ${ }^{5}$

Keberhasilan pemberlakuan pembinaan di satu sisi berdampak baik jika sadar dan tidak mengulangi perbuatan tersebut dan penyesalan atas perbuatannya. Sisi lain hukum tersebut dapat juga menimbulkan yaitu diantaranya: (1) Pengenaan pembinaan terhadap anak, maka dirinya selalu menghindar dengan pengasuh, sehingga secara tidak langsung berakibat hubungan terputus diantara keduanya. (2) Dengan penerimaan pembinaan tersebut, bahwa harga dirinya terlanggar, anak merasa malu. Dua hal tersebut harus diperhatikan oleh pengasuh karena dari segi psikologis, pembinaan yang tidak wajar membuat anak merasa tidak nyaman. Pembinaan yang tidak tepat harus dihindarkan karena berakibat rusaknya hubungan anak dengan pengasuh, maka seharusnya sanksi yang diberikan harus dapat membangkitkan rasa kesusilaan. ${ }^{6}$

Berdasarkan dari penjelasan hak-hak anak panti asuhan merupakan tempat anak yang ditinggal orang tua atau tidak mampu. Maka perlu mempertimbangkan penerapan sanksi serta dampak yang akan diterima anak, hal tersebut diterapkan di panti asuhan dalam rangka mengubah sikap anak agar mengurangi bahkan tidak melanggar disiplin lagi. Kontradiksi penerapan sanksi untuk meningkatkan kedisiplinan anak sebagai jaminan perkembangan kematangan dan kedewasaan anak dengan tanpa mengalami tindak kekerasan, intimidasi dan diskriminasi. Hal tersebut bertujuan terwujudnya anak yang memiliki kualitas dalam berfikir dan akhlak yang mulia.

Perlindungan merupakan suatu hak konstitusional yang menghadirkan kebahagian dan kesejahteraan baik masa kini dan masa yang akan datang. Oleh sebab itu prinsip yang terkait dengan perwujudan perlindungan tidak hanya terkait peraturan yang mengaturnya, tetapi juga struktur pelaksananya yaitu diantaranya masyarakat dan lingkungan agar tercipta masa depan yang lebih baik. ${ }^{7}$

Dalam mengelola suatu lembaga merupakan bagian kemampuan atau keterampilan seseorang atau lembaga dalam melaksanakan kegiatan menyangkut diri sendiri dan orang lain

\footnotetext{
${ }^{5}$ Abu Ahmadi dan Nur Uhbiyati, Ilmu Pendidikan, (Jakarta, PT Rineka Cipta, 2015), cet. ke III, hal. 151.

${ }^{6}$ Abu Ahmadi dan Nur Uhbiyati, Ilmu Pendidikan, ..., hal. 152.

${ }^{7}$ Muhammad Fachri Said, perlindungan hukum terhadap anak dalam perspektif hak asasi manusia, Jurnal Cendekia Hukum: Vol. 4, No 1, September 2018, hlm. 145
}

Al Qalam: Jurnal Ilmiah Keagamaan dan Kemasyarakatan Vol. 16, No. 2

Maret - April 2022 
dalam rangka mewujudkan suatu pencapaian berupa kebersamaan hingga kebahagiaan serta termasuk pula berpendidikan yang terampil. ${ }^{8}$

Maka penulis ingin mengetahui apa yang terjadi di panti asuhan Misbaahun Munir Kota Tenggarong dalam penerapan sanksi terhadap anak dan bagaimana penerapan sanksi untuk meningkatkan disiplin anak, dengan diterapkannya sanksi apakah berdampak pada anak dan penerapan sanksi tersebut dalam perspektif undang-undang perlindungan anak.

\section{METODE PENELITIAN}

Jenis dalam penelitian ini yaitu penelitian empiris (Field research) dengan menggunakan pendekatan kualitatif. Penelitian empiris atau lapangan dilakukan di Panti Asuhan Misbaa Hun Muniir Kota Tenggarong Provinsi Kalimantan Timur. Kemudian dilakukan pengumpulan data dengan menggunakan teknik observasi dan wawancara. Selanjutnya teknik analisis dalam kajian ini menggunakan data diantaranya reduksi, penyajian, dan kesimpulan.

\section{HASIL DAN PEMBAHASAN}

\section{Pengaturan Perlindungan Anak}

Berdasar Piagam Pernyataan Negara anggota PBB menjamin perlindungan atas hak asasi manusia, harkat martabat, kebahagian, dan kesejahteraan sosial. Terwujudnya perlindungan tersebut merupakan bagian dari keberhasilan negara-negara sehingga negara tersebut dapat dikategorikan berhasil. Dalam Deklarasi Sedunia tentang Hak Asasi Manusia tersebut PBB menyatakan sesungguhnya tiap orang memiliki hak atas segala sesuatu dengan tanpa membedabedakan agama, jenis kelamin, bahasa, keturunan, suku bangsa, politik dan lainnya. Termasuk juga tingkatan dalam masyarakat baik miskin atau kaya dan juga pendidikan. Selanjutnya sebagai dasar pertimbangan terhadap belumnya kematangan anak, maka dari itu bentuk perlindungannya berbeda dengan perlindungan yang telah dewasa. Hal ini berakibat pada perlindungan yang sifatnya lebih khusus yang diakui sedunia diatur dalam Deklarasi Jenewa tentang Hak Anak-anak tahun 1924 terkait badan-badan khusus yang menegakan dan memperjuangkan kebahagian anak. Selain itu, dalam deklarasi tersebut menegaskan bahwa seluruh umat manusia memiliki kewajiban untuk memperjuangkan kebaikan bagi perkembangan anak. Oleh karena itu, ketika anak-anak saat menjalani masa-masa kecilnya hingga beranjak dewasa tidak terkekang dan merasakan kebahagiaan. Selanjutnya deklarasi tersebut memerintahkan berbagai pihak baik orang tua, wali,

${ }^{8}$ Andi Muhammad Asbar, Strategi Guru Dalam Pengelolaan Kelas Pada Pembelajaran Pendidikan Agama Islam Di Smp Negeri 39 Bulukumba STAI Al-Gazali Bulukumba, Sulawesi Selat, Jurnal Ilmiah Al QALAM, Vol. 12, No. 1, Januari-Juni 2018, hlm. 95

Al Qalam: Jurnal Ilmiah Keagamaan dan Kemasyarakatan Vol. 16, No. 2 Maret - April 2022 
organisasi masyarakat, dan organisasi pemerintah agar memberikan hak tersebut sesuai amanat peraturan perundang-undangan yang dibuat oleh Pemerintah. ${ }^{9}$

Perlindungan terhadap anak dalam hukum internasional diatur dalam Konvensi Hak Anak 1989, ketentuan tersebut menempatkan negara memiliki kewajiban sebagai pelindung anak sebab belum memiliki kematangan berfikir. Dalam ketentuan Pasal 3 ayat (2) menyebutkan bahwa negara-negara yang bergabung harus mewujudkan agar anak memperoleh kesejahteraan dan kebahagian. Maka negara perlu mempertimbangkan semua hak dan tangungjawab terhadap anak, serta memperjuangkan bahwa sesungguhnya tiap anak mempunyai haknya dalam bersosialisasi serta menjamin semua itu hingga tercapainya kehidupan dan perkembangan anak yang lebih baik.

Selanjutnya Pasal 19 ayat (a) Konvensi Hak Anak 1989 dapat disimpulkan bahwa bagi negara yang termasuk negara peserta untuk dapat membuat aturan sebagai pijakan untuk mewujudkan perlindungan atas anak dari segala tindak kekerasan, penyalahgunaan hingga menelantarkan anak.

Convention on The Rights of the Child (CRC) atau Konvensi Hak Anak (KHA) merupakan instrument/ aturan internasional tentang hak-hak anak. Atas dasar itu Indonesia melakukan ratifikasi atas ketentuan internasional melalui Keputusan Prensiden Nomor 36 Tahun 1990. Khususnya negara yang bergabung untuk meratifikasi suatu konvensi. Secara tidak langsung hal ini berakibat terikat baik secara politik maupun hukum/ yuridis. Oleh karena terikat hukum, dalam perkembangannya Indonesia mempunyai kewajiban dalam pengembangan dalam bentuk kebijakan dan peraturan perundang-undangan.

Selanjutnya sebagai konsekuensi memenuhi secara yuridis akibat dari ratifikasi hukum. Dalam perkembangannya saat ini lahir Undang-Undang Nomor 23 tahun 2002 tentang Perlindungan Anak adalah bagian dari mewujudkan salah satu tugas negara. Saat proses menyusun ketentuan peraturan tersebut, maka mendudukan Konvensi Hak Anak sebagai rujukan utama atau dasar, yang sesuai dengan norma-norma sosial yang berlaku di Indonesia. Secara politik bernegara, kewajiban negara secara terus-menerus memperbaiki sistem dengan tujuan menciptakan kebahagian dan kesejahteraan anak. ${ }^{10}$

Suatu negara memiliki tanggungjawab untuk memberikan jaminan terhadap kebahagiaan anak secara yuridis dalam konstitusi Indonesia. Secara hierarki pengesahan pemberlakuan produk peraturan merupakan pijakan dalam membuat kebijakan dan sebagai batasan memperlakukan

\footnotetext{
${ }^{9}$ Bismar Siregar, Abdul Hakim Garuda Nusantara, Suwanji Sisworahardjo, Arif Gosita, Mulyana W. Kusuma (Penyunting), Hukum dan Hak-Hak Anak, (Jakarta: C.V. Rajawali, 1986), hal. 64-65.

10 Mohammad Taufik, Wenny Bukamo dan Syaiful Azri, Hukum Perlindungan Anak, Dan Penghapusan Kekerasan Dalam Rumah Tangga, ..., hal. 1.
}

Al Qalam: Jurnal Ilmiah Keagamaan dan Kemasyarakatan Vol. 16, No. 2 Maret - April 2022 
anak. Ketentuan tersebut baik produk hukum nasional sendiri dan produk dari luar yang sudah diratifikasi. ${ }^{11}$

Dalam Undang-undang Republik Indonesia Nomor 35 Tahun 2014 Tentang Perubahan Atas Undang-Undang Republik Indonesia Nomor 23 Tahun 2002 Tentang Perlindungan Anak, pada ketentuan umum pasal 10, anak asuh adalah anak yang mendapat pengasuhan oleh seseorang atau organisasi/ lembaga yang dapat memberikan pembimbingan, pemeliharaan, pendidikan, dan kesehatan, sebab orang tuanya atau salah satu orang tuanya tidak mampu memberikan jaminan pertumbuhan dan perkembangan anak.

Salah satu lembaga yang dimaksud ketentuan tersebut adalah panti asuhan. Sebagaimana ketentuan Keputusan Menteri Sosial Nomor 15 A tentang Panduan Umum Program Kesejahteraan Sosial Anak merupakan landasan yuridis bagi panti asuhan untuk melaksanakan program pemerintah.

Sebab panti asuhan tersebut terikat secara yuridis maka berkewajiban melaksanakan UU Perlindungan Anak yang terdapat pada asas dan tujuan Pasal 2 menyebutkan bahwa penyelenggara perlindungan anak berasaskan Pancasila dan Undang-Undang Dasar NRI Tahun 1945 dan Konvensi Hak-hak Anak meliputi: (a) nondiskriminasi; (b) kepentingan yang terbaik bagi anak; (c) hak untuk hidup, kelangsungan kehidupan, dan perkembangannya; dan (d) memberikan penghargaan kepada pendapat yang diajukan anak. Selanjutnya Pasal 3 bahwa perlindungan terhadap anak memiliki tujuan agar terjaminnya hak-hak anak agar dapat hidup, tumbuh, berkembang, dan berpartisipasi secara optimal sesuai denga harkat dan martabat kemanusiaan, serta mendapat perlindungan dari tindakan kekerasan dan juga diskriminasi sehingga terwujudnya anak Indonesia yang memiliki kualitas, berakhlak mulia, dan sejahtera.

Keberadaan UU Perlindungan Anak, saat panti asuhan menerapkan pembinaan harus sesuai standar atau kriteria dalam peraturan perundang-undangan. Maka standar atau kriteria tersebut menjadi ukuran dalam memperlakukan anak. Maka dalam ketentuan Pasal $13 \mathrm{UU}$ Perlindungan Anak menyatakan yaitu:

1) Setiap anak yang selama dalam asuhan atas orang tua, wali atau pihak lain manapun, kesemuanya yang bertanggung jawab atas pengasuhan, sehingga anak berhak mendapat perlindungan dari segala perlakuan:
a. Diskriminasi
b. Eksploitasi, baik ekonomi maupun seksual;
c. Penelantaran;

${ }^{11}$ Sri Ismawati, Mekanisme Penyelesaian Perkara Anak Yang Berhadapan Dengan Hukum Pada Masyarakat Dayak Kanayatn (Kajian Perbandingan Terhadap Sistem Peradilan Pidana Anak), Jurnal Dinamika Hukum, Vol. 13, No. 2, 2013, hlm. 197

Al Qalam: Jurnal Ilmiah Keagamaan dan Kemasyarakatan Vol. 16, No. 2 Maret - April 2022 
d. Kekejaman, kekerasan, dan penganiayaan;

e. Ketidakadilan; dan

f. Perlakuan salah lainnya.

2) Terkait dengan orang tua, wali atau pengasuh anak dalam melakukan segala bentuk.

3) Pemberlakuan sebagaimana dimaksud dalam ayat (1), maka pelaku dikenakan pemberatan pembinaan.

Hak anak yang tercantum dalam Undang-Undang tentang Perlindungan Anak tersebut antara lain meliputi hak yaitu

a. Untuk memperoleh penghidupan, pertumbuhan, perkembangan dan mampu berpartisipasi secara wajar yang sesuai dengan harkat dan martabat kemanusiaan serta memperoleh perlindungan dari kekerasan dan diskriminasi;

b. Berdasar atas nama sebagai identitas dan status kewarganegaraan;

c. Melaksanakan beribadah berdasar agamanya, pemikiran dan kreatifitas sesuai dengan tingkat kecerdasan dan usianya dalam naungan pembimbingan orang tua;

d. Untuk mengenal siapa orang tuanya, yang dibesarkan dan diasuh oleh orang tuanya sendiri;

e. Mendapatkan pelayanan baik kesehatan dan jaminan sosial yang sesuai dengan kebutuhan fisik, mental, spiritual dan sosial;

f. Mendapatkan pendidikan serta pengajaran dalam rangka pengembangan kepribadian dan peningkatan tingkat kecerdasan sesuai dengan minat dan bakatnya;

g. Memperoleh pendidikan luar biasa, rehabilitasi, bantuan sosial dan pemeliharaan taraf kesejahteraan sosial bagi anak yang menyandang cacat;

h. Mendapat pendidikan khusus khususnya bagi anak yang memiliki keunggulan;

i. Menghargai pendapatnya, untuk menerima, mencari dan memperoleh informasi yang sesuai pada tingkat kecerdasan dan usianya demi perkembangannya selaras dengan nilai-nilai kesusilaan dan kepatutan;

j. Untuk beristirahat dan memanfaatkan waktu luang, bergaul dengan anak yang sebaya, bermain, berekreasi dan berkreasi sesuai dengan minat, bakat dan tingkat kecerdasannya demi pengembangan diri;

k. Mendapat perlindungan dari perlakuan diskriminasi, eksploitasi (baik ekonomi maupun seksual), penelantaran, kekejaman, kekerasan, penganiayaan, ketidakadilan serta perlakuan salah lainnya;

1. Pengasuhan oleh orang tuanya sendiri kecuali terdapat alasan dan/atau aturan hukum yang dibenarkan bahwa pemisahan tersebut dengan pertimbangan demi kepentingan terbaik bagi anak dan hal tersebut merupakan pertimbangan terakhir;

Al Qalam: Jurnal Ilmiah Keagamaan dan Kemasyarakatan Vol. 16, No. 2

Maret - April 2022 
m. Memperoleh perlindungan dari sasaran penganiayaan, penyiksaan atau penjatuhan pembinaan yang tidak manusiawi;

n. Memperoleh kebebasan sesuai dengan hukum;

o. Memperoleh perlakuan secara manusiawi dan menempatkan dirinya terpisah dari orang dewasa, memperoleh bantuan hukum atau bantuan lainnya secara efektif dan setiap upaya hukum yang berlaku, serta membela diri dan memperoleh keadilan di Pengadilan Anak yang objektif dan juga tidak memihak;

p. Menjaga kerahasian anak baik sebagai korban maupun pelaku kriminal atau yang berhadapan dengan hukum; dan

q. Memperoleh bantuan hukum dan juga bantuan-bantuan lainnya, khususnya pada anak yang menjadi korban atau juga pelaku kriminal.

\section{Strategi Pembinaan di panti Asuhan Misbaa Hun Muniir Kota Tenggarong}

Pihak yang bertanggungjawab atas perlindungan hukum secara bersama-sama diantaranya yaitu orang tua, keluarga, masyarakat, pemerintah, dan juga negara. Kesemuanya bertanggungjawab dalam hal berbagai kehidupan baik agama, pendidikan, kesehatan dan sosial. ${ }^{12}$

Penerapan perlindungan anak yang menjadi dasar pertimbangan yaitu diantaranya: 1) Dasar Filosofis, maksudnya bahwa Pancasila sebagai pijakan dasar segala sesuatu pelaksanaan dalam menjalankan kehidupan diantaranya hubungan keluarga, bermasyarakat, bernegara, dan berbangsa; 2) Dasar Etis, maksudnya bahwa pemberlakuan atas perlindungan anak diharuskan untuk selaras dengan etika profesi. Hal itu menjadi pijakan yang bertujuan untuk terhindarnya perilaku menyimpang atau penyalahgunaan kekuasaan dalam pemberlakuan dan penegakan perlindungan anak; 3) Dasar Yuridis, maksudnya bahwa pelaksanaan perlindungan anak berpijak pada ketentuan peraturan yang berlaku yaitu Undang-Undang Dasar NRI 1945 serta berbagai peraturan perundang-undangan pelaksana perlindungan anak. Ketentuan yuridis tersebut harus secara integratif, yaitu mengharmonisasikan antar peraturan perundang-undangan yang saling terkait. ${ }^{13}$

Perwujudan perlindungan terhadap anak terdapat beberapa pilar yang saling terkait erat satu dengan lainnya diantaranya, orang tua, keluarga, masyarakat, dan pemerintah. Bentuk perlindungan anak tersebut yaitu dengan memberikan jaminan dan perlindungan hak sesuai harkat dan martabat kemanusian untuk hidup, tumbuh, berkembang, sehingga anak dapat turut serta terhidar dari segala bentuk kekerasan dan diskriminasi. Namun realita kondisi anak-anak di

12 Noer Indriati, Pengembangan Model Perlindungan Hukum Terhadap Anak Sebagai Korban Perdagangan Di Indonesia, Jurnal Dinamika Hukum, Vol. 14, No. 3, 2014, hlm. 409

13 Arif Gosita, 1999, Aspek Hukum Perlindungan Anak dan Konvensi Hak-hak Anak, Jakarta, Era Hukum, Jurnal Ilmiah Ilmu Hukum. No. 4/Th.V/April 1999, hlm. 266-267

Al Qalam: Jurnal Ilmiah Keagamaan dan Kemasyarakatan Vol. 16, No. 2 Maret - April 2022 
Indonesia cenderung memprihatinkan seperti keberadaan pekerja anak, anak jalanan, dan lainlainnya. ${ }^{14}$

Proses dalam perumusan tata tertib yang dapat dilakukan untuk menciptakan kedisiplinan. Untuk mencapai hal tersebut maka perumusan tata tertib perlu melibatkan semua pihak dengan menyesuaikan visi dan misi panti asuhan. Kesepakatan tersebut merupakan hasil dari kehendak bersama terkait segala perbuatan terlarang serta pembinaannya, kesemua itu merupakan hasil resultante berbagai pihak yaitu anak, pengasuh, pengurus dan ketua panti asuhan, yang didasarkan pada komitmen bersama.

Pada tanggal 28 oktober 2018 diadakan evaluasi setelah mendapat beberapa catatan laporan tentang keadaan anak dan diadakan pencerahan dan penjelasan untuk membina anak yang mempunyai masalah selama sebulan ini. Hal tersebut dilakukan Panti Asuhan Misbaa Hun Muniir Kota Tenggarong agar pelanggaran tata tertib yang bersifat kedisiplinan dapat dikurangi begitu juga pelanggaran yang lain. Perkembangan anak selama sebulan yang kurang baik dan baik dapat mempengaruhi lingkungan sekitar, sehingga diperlukan pembinaan seperti ini secara berkelanjutan.

Menurut Didi Syahrianto selaku ketua Panti Asuhan Misbaa Hun Muniir, beliau menerangkan terkait pembinaan atas kedisiplinan anak harus diterapkan setiap hari, melalui pengawasan yang tegas kepada anak yang dilakukan oleh pengasuh, pengurus dan staff panti asuhan agar tercipta lingkungan yang nyaman bagi anak dan masyarakat sekitar. Selanjutnya anak yang bermasalah, hal tersebut perlu ditindaklanjuti dengan segera, sebab menghindari akibat yang tidak diinginkan dari perbuatan tersebut, dengan menaati peraturan yang telah ditentukan diharapkan dapat mengurangi tingkah laku yang merugikan bagi anak dan lingkungannya. ${ }^{15}$

Berdasar ketentuan peraturan tata tertib yang telah dibuat secara bertahap dari bentuk pertama pelanggaran ringan, kedua pelanggaran sedang hingga ketiga pelanggaran berat. Perilakuperilaku tersebut antara lain; terlambat sholat, meninggalkan asrama, membolos sekolah, mencoret dinding, membuka aurat, rambut panjang, membawa telpon genggam, merokok, membawa senjata tajam sehingga berujung tindakan kriminal dan lainnya yang diatur dalam tata tertib. Maka keberadaan panti asuhan sebagai lembaga yang amanah yang melaksanakan pengasuhan dan pemenuhan hak anak. Keberadaan pengurus dan pengasuh di panti asuhan diharapkan mampu menyelenggarakan pengasuhan dan pemenuhan hak anak yang mampu menciptakan perilaku yang baik. Perilaku tersebut ditunjukan dalam bentuk seperti bersosiali

\footnotetext{
${ }^{14}$ Rini Fitriani, Peranan Penyelenggara Perlindungan Anak Dalam Melindungi Dan Memenuhi HakHak Anak, Jurnal Hukum Samudra Keadilan, Volume 11, Nomor 2, Juli-Desember 2016, hlm. 250

${ }^{15}$ Hasil Wawancara dengan Drs Didi Syahrianto selaku Ketua Panti Asuhan Misbaa Hun Muniir dilaksanakan pada pada Pukul 16.00 Wita Hari Minggu Tanggal 28 Oktober 2018 di ruang kantor.
}

Al Qalam: Jurnal Ilmiah Keagamaan dan Kemasyarakatan Vol. 16, No. 2 Maret - April 2022 
yang baik dengan masyarakat, serta menunjukkan perilaku yang beretika dan berakhlak mulia, sehingga berguna bagi masyarakat dan negara.

Saat wawancara dengan Ketua Panti Asuhan Misbaa Hun Muniir Kota Tenggarong menyatakan bahwa latar belakang pengenaan pembinaan bertujuan untuk mengarahkan anak terkait sikap dan perilaku. Pembinaan yang dikenakan diantaranya berupa teguran, nasehat, konseling dan pembinaan lainnya. Sebagaimana teori perbaikan atas pembinaan tersebut bertujuan agar anak memperbaiki kesalahan dan tidak mengulangi lagi pelanggaran. Sifat normatif dalam hukum tersebut yaitu memperbaiki akhlak anak. Jenis pembinaan tersebut merupakan bagian dari pelayanan berupa bimbingan dan perbaikan baik pribadi maupun kelompok. ${ }^{16}$

Menurut Sekretaris panti asuhan bahwa mekanisme penerapan sanksi bagi anak yang melakukan kesalahan sebagaimana tata tertib panti asuhan, setiap pelanggaran dicatat di buku pembinaan. Sehingga semua kesalahan anak tersebut tercatat. Hal tersebut menentukan berat ringannya pembinaan pelanggaran, sebab tingkat kesalahan dan banyaknya menentukan kadar pembinaannya. ${ }^{17}$

Selanjutnya wawancara dengan bapak Candra sebagai pengasuh dalam melaksanakan penjatuhan sanksi terdiri dari tahapan-tahapan sebagai bagian dari pembinaan dari pengasuh di Panti Asuhan Misbaa Hun Muniir Kota Tenggarong yaitu tingkatan pelanggaran meliputi pelanggaran ringan, sedang dan berat. Dengan demikian tingkatan tersebut yaitu:

1) Sanksi pelanggaran ringan yaitu

a. Teguran dan peringatan

b. Hafalan Al-Qur'an

c. Hafalan Do'a

d. Sholat Sunah

2) Sanksi pelanggaran sedang yaitu

a. Surat peringatan I dan konseling

b. Hafalan ayat lebih banyak dari pelanggaran ringan

c. Hafalan do'a lebih banyak dari pelanggaran ringan

d. Sanksi sosial yang mana sanksi tersebut harus menyesuaikan dengan dengan tingkatan pelanggaran

3) Sanksi pelanggaran berat yaitu diantaranya

a. Surat peringatan II

\footnotetext{
${ }^{16}$ Hasil Wawancara dengan Drs Didi Syahrianto selaku Ketua Panti Asuhan Misbaa Hun Muniir dilaksanakan pada Pukul 17.30 Wita Hari Selasa Tanggal 23 Oktober 2018 di ruang kantor.

17 Hasil Wawancara dengan Iskandar selaku sekretaris Panti Asuhan Misbaa Hun Muniir dilaksanakan pada Pukul 16.00 Wita Hari Rabu Tanggal 24 Oktober 2018 di ruang kantor.
}

Al Qalam: Jurnal Ilmiah Keagamaan dan Kemasyarakatan Vol. 16, No. 2

Maret - April 2022 


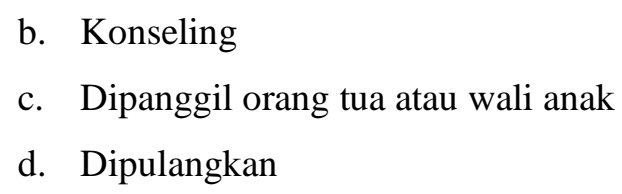

Sehingga anak yang melakukan pelanggaran akan menerima sanksi yang sesuai berdasar tingkatan tiap tindakan pelanggaran. Dari tahapan-tahapan tersebut Panti Asuhan Misbaa Hun Muniir Kota Tenggarong menjadi ukuran membina terhadap siswa yang melakukan pelanggaran tata tertib panti asuhan. Maka tingkatan pembinaan terhadap anak yaitu diantaranya:

1) Pelanggaran ringan pelaksana pengasuh

2) Pelanggaran sedang pelaksana pengasuh dan konseling

3) Pelanggaran berat pelaksana konseling dan rapat pengurus panti asuhan

Penerapan sanksi yang ada di Panti Asuhan Misbaa Hun Muniir Kota Tenggarong pada anak yang dilaksanakan oleh badan pelaksana. Pembentukan badan tersebut oleh panti asuhan, selanjutnya dibentuk mekanisme kerja atau petunjuk teknis dalam pelaksana serta penegakan peraturan tata tertib.

Berdasar hasil wawancara dapat disimpulkan bahwas pelaksanaan pembinaan di Panti Asuhan Misbaa Hun Muniir Kota Tenggarong mengedepankan pembinaan secara edukatif, bukan pembinaan fisik yang berbentuk kekerasan. Jenis pembinaan yang diberlakukan kepada anak sehingga anak menyadari kesalahannya yang diperbuat yaitu pembinaan mental/ psikis melalui cara dengan memberi klasifikasi atas tingkatan pembinaan ringan, sedang dan berat.

Beberapa bentuk-bentuk sifar pelanggaran berupa; 1) Sifat pengingat yaitu berupa teguran dan/ atau peringatan; 2) Sifat administratif yaitu membuat surat pernyataan tidak mengulangi perbuatan dan surat pemanggilan orang tua / wali anak; 3) Sifat pembinaan yaitu hafalan, sholat sunah dan konseling; dan 4) Sifat sosial yaitu membersihkan sampah di wilayah panti asuhan, menyapu asrama dan lain-lain

\section{KESIMPULAN}

Sebagaimana amanat dalam Undang-Undang Republik Indonesia Nomor 35 Tahun 2014 Tentang Perubahan Atas Undang-Undang Nomor 23 Tahun 2002 Tentang Perlindungan Anak Pasal 59 ayat (2) huruf b Perlindungan Khusus terhadap anak yang melakukan pelanggaran hukum dilakukan diantaranya: a. perlakuan secara manusiawi dengan memperhatikan kebutuhan sesuai dengan umurnya. Perlakuan secara manusia dalam ketentuan tersebut pada penerapan sanksi di Panti Asuhan Misbaa Hun Muniir Kota Tenggarong yaitu dengan membuat pembinaan bagi anak yang bermasalah dengan berdasar tingkatan kesalahan diantarannya pelanggaran ringan,

Al Qalam: Jurnal Ilmiah Keagamaan dan Kemasyarakatan Vol. 16, No. 2

Maret - April 2022 
sedang dan berat. Tingkatan dalam sanksi tersebut merupakan bagian dari usaha pembinaan untuk mendidik anak agar menjadi lebih baik.

\section{DAFTAR PUSTAKA}

Ahmadi, Abu dan Nur Uhbiyati, Ilmu Pendidikan, (Jakarta, PT Rineka Cipta, 2015), cet. ke III.

Asbar, Andi Muhammad, Strategi Guru Dalam Pengelolaan Kelas Pada Pembelajaran Pendidikan Agama Islam Di Smp Negeri 39 Bulukumba, STAI Al-Gazali Bulukumba, Sulawesi Selat, Jurnal Ilmiah Al Qalam, Vol. 12, No. 1, Januari-Juni 2018.

Fithriah, Nor, Kepemimpinan Pendidikan Pesantren (Studi Kewibawaan Pada Pondok Pesantren Salafiyah, Modern, dan Kombinasi), Jurnal Ilmiah Al Qalam, Vol. 12, No. 1, JanuariJuni 2018.

Fitriani, Rini, Peranan Penyelenggara Perlindungan Anak Dalam Melindungi Dan Memenuhi Hak-Hak Anak, Jurnal Hukum Samudra Keadilan, Volume 11, Nomor 2, Juli-Desember 2016.

Gosita, Arif, 1999, Aspek Hukum Perlindungan Anak dan Konvensi Hak-hak Anak, Jakarta, Era Hukum, Jurnal Ilmiah Ilmu Hukum. No. 4/Th.V/April 1999.

Gultom, Maidin, Perlindungan Hukum Terhadap Anak dalam Sistem Peradilan Pidana Anak di Indonesia, (Bandung: PT Refika Aditama, 2014), cet. ke IV.

Indriati, Noer, Pengembangan Model Perlindungan Hukum Terhadap Anak Sebagai Korban Perdagangan Di Indonesia, Jurnal Dinamika Hukum, Vol. 14, No. 3, 2014,

Ismawati, Sri, Mekanisme Penyelesaian Perkara Anak Yang Berhadapan Dengan Hukum Pada Masyarakat Dayak Kanayatn (Kajian Perbandingan Terhadap Sistem Peradilan Pidana Anak), Jurnal Dinamika Hukum, Vol. 13, No. 2, 2013.

Prayitno, Iwan, Anakku Penyejuk Hatiku, (Bekasi: Pustaka Tarbatuna, 2004), cet. ke II, hal. 416.

Said, Muhammad Fachri, Perlindungan Hukum Terhadap Anak Dalam Perspektif Hak Asasi Manusia, Cendekia Hukum: Vol. 4, No 1, September 2018.

Siregar, Bismar, Abdul Hakim Garuda Nusantara, Suwanji Sisworahardjo, Arif Gosita, Mulyana W. Kusuma (Penyunting), Hukum dan Hak-Hak Anak, (Jakarta: C.V. Rajawali, 1986).

Sudrajat, Tedy, Perlindungan Hukum Terhadap Hak Anak Sebagai Hak Asasi Manusia Dalam Perspektif Sistem Hukum Keluarga Di Indonesia, Kanun Jurnal Ilmu Hukum, Vo. 13, No. 2, 2011.

Taufik, Mohammad, Wenny Bukamo dan Syaiful Azri, Hukum Perlindungan Anak, Dan Penghapusan Kekerasan Dalam Rumah Tangga, (Jakarta: PT Rineka Cipta, 2013), cet. ke I.

Al Qalam: Jurnal Ilmiah Keagamaan dan Kemasyarakatan Vol. 16, No. 2

Maret - April 2022 